\title{
Buying Books on a Budget
}

$\mathrm{T}$ HE building of personal libraries has long been encouraged at Rockford College. The college is always looking for new ideas to develop student interest in books. A flexible book program has led to many interesting projects. ${ }^{1}$ The Maddox Book House, with its old book room containing eighteenth- and nineteenth-century English and French books, brought profitable pleasure to students for twelve years, to terminate only because a depleted stock could not be replaced during the war. A browsing bookstore delighted campus booklovers and gave many students an informal but new approach to reading. When crowded campus conditions are relieved it will be reestablished. Book prizes awarded for outstanding performances, curricular and extracurricular, were selected by the students from the browsing bookstore. Inglenook, the dormitory collection selected by the student library committee, offers opportunity for recreational reading in informal surroundings. A new college bookstore, specializing in reprints and special press books, is now rapidly developing in new and attractive quarters.

The newest project to encourage the

${ }^{1}$ The following articles have been published on book projects at Rockford College.

"From London to Midwest Campus Each Autumn Comes a Shipment of Rare Old Books." Christian Science Monitor, Nov. 11, 1941.

Frost, Lesley. "Maddox House Bookshop." Pub. lishers' Weekly 126:1 742-44, Nov. 10, 1934.

ishers Weekly r26:1742-44, Nov. I0, 1934.
Sharpe, Jean MacNeill. "The Book Program of Sharpe, Jean MacNeill. "The Book Program of
Rockford College." Illinois Libraries 18:217-19, August 1938 .

Sharpe, Jean MacNeill. "Reading for Recreation at Rockford College." Library Journal 62:576-77, August r 938 .

1938. Thompson, Margaret S. "The Book House at Rockford College." School and Society 46:87-89, July 17 , 1937.

Wilde, Louise K. "The Old Book Room at Rock June 1940. building of personal libraries was a contest sponsored by the college library. There were only two rules for the contest. The personal library had to be built around, first, a core idea or central theme, and, second, no more than fifteen dollars could be spent on the collection.

The first rule of the contest in no way limited the student's choice of subject. The theme could be broad or narrow, it could be in a special field of study, it could be of general or specific interest, but each book had to have a purpose, each book had to have its place with the others. Stress was placed on a core idea that truly expressed the individual's interest. The collections resulted in personal libraries the participants want to keep, to read, to reread. Whether the collections were scholarly in content or naive in an amateur approach to a simple hobby was unimportant if the collection was of sincere interest to its owner.

As the contest progressed it developed some of the entrants already had sizable collections. Their challenge became a rounding out of what they already had. For most of the entrants the contest was the opening of new vistas in the world of books.

The second rule of the contest was that not more than fifteen dollars could be spent on the collection. Benjamin Franklin once wrote a friend: "I am not rich enough to afford much in good works, and so am obliged to be cunning and to make the most of a little." By setting the amount at fifteen dollars thriftiness was encouraged. Many asked, "How can I collect a personal li- 
brary for only fifteen dollars?" but with so small a sum all students could afford to enter the contest.

Because the contestants were unaware of ways to buy inexpensive books, it was necessary to show them how to buy books, good books, inexpensively and easily. No attempt was made to deal with rare or scarce items on the book market, but with books that cost little. Two types of books were stressed in the gathering of the libraries, reprint editions and secondhand books.

Recently publishers have realized there is a market for inexpensive books. Everyman's Library, World's Classics, and Modern Library have brought out reprints with good format which may be procured for little more than a dollar. Sometimes a good reprint can be picked up at the corner drugstore in the twenty-five-cent paper-covered editions.

Secondhand bookstores are exciting places, yet few students had discovered them. Small groups of students visited some of the larger general Chicago secondhand bookstores. They had an opportunity to browse and purchase under informal professional guidance. They all went with open minds about selecting books, though were forewarned that a specific title is often difficult to find, and came back enthusiastic about the trip. They had discovered the fascination of selecting and purchasing used books in old bookstores.

\section{Spring Book Fair}

A spring book fair was held soon after the announcement of the book contest. The books sold were remainders from Maddox collections purchased in England and France before the war. The volumes, sorted according to price, were placed on tables marked with names of English bookshops. For two days the whole college community had an opportunity to browse and purchase.
The proceeds of the sale went for a new order of secondhand books purchased from Hardings in London for a second book fair.

A book auction held in the fall gave the entrants of the book contest another opportunity to purchase secondhand volumes. The books in the browsing bookstore collection at Maddox House were sorted by a student committee, arranged by a broad subject classification, placed on exhibit for several days, then auctioned to the highest bidder.

A permanent book contest exhibit placed in a prominent spot in the college library consisted of representative copies of reprint series ordered from the publishers, with publishers' reprint sales lists and publishers' catalogs. With these editions was the Catalog of Reprints in Series. Several articles on reprints by Kelsey Guilfoil which appeared in the Chicago Tribune Books were clipped and mounted. A few of the books on the gathering of a personal library placed on exhibit were:

A. Edward Newton's The Amenities of Book Collecting

A. Edward Newton's Bibliography and Pseudo-Bibliography

A. Edward Newton's End Papers

H. F. West's Modern Book Collecting for the Impecunious Amateur

A. S. W. Rosenbach's A Book Hunter's Holiday

Holbrook Jackson's The Anatomy of Bibliomania

J. T. Winterich's A Primer of Book-collecting Christopher Morley's Ex Libris Carissimis Christopher Morley's The Haunted Bookshop Christopher Morley's Parnassus on Wheels

This exhibit aroused much interest. Here the students browsed, read the books on book collecting, looked at and checked secondhand sales catalogs, checked books in reprint lists, and looked at the samples of reprint series.

For the final judging of the contest the contestants placed their collections on 
tables in the college library. Varied ideas, showing personal interests, were displayed. The winner of the contest, whose hobby is horses, chose "Corralling a Hobby Horse in a Book Stall" as her topic. She made use of government documents, both federal and state, reprint editions, new and secondhand books. Her written comments handed in at the time of the judging suggest what one student gained from joining the contest.

Considered as a whole experience, beginning this library has been an exciting undertaking, surprisingly related to many of our activities at Rockford. Since the amount of money to be spent was limited, we were forced to use more discretion in selecting entries. What's more, learning to use "search-savers" in tracking down appropriate books has been invaluable. Handy aids like the Cumulative Book Index, The Book Review Digest, and the government printing catalogs saved much time and guesswork. Visiting secondhand book stores was a picnic; making it a habit should certainly simplify "corralling" other topics.

All these angles, so new to me, have made book collecting more than just worth while; it's a whale of a lot of fun besides; fun that can last a lifetime!

Not only did the winner have a good collection of books but displayed them attractively, placing all the books in a paddock and using riding boots for book ends.

One already impressive personal library was supplemented for the contest by a senior whose subject field, philosophy, was the basis for her collection, "A Beginner's Library of Contemporary Philosophy." She shared the second prize with another senior who selected the simple idea, "Books I Like." Being an art major her library included books on art, philosophy, and poetry. The freshman prize went to a collection entitled "Verses: Best and Brightest, From Ancient Muse to Modern Miss." Honorable mention was given to a sophomore whose collection showed an exceptionally wide range around her core idea, "Drama."

Some core ideas were scholarly and followed closely major fields of study, as "Literature of the Spanish Language," "Beginnings of a History of English Poetry," "English Drama," "A Beginner's Study of the Bible," and "The Evolution of British Drama." Others were based on hobbies as "Books I Have Read During the School Year," "Stories that Never Grow Old," "Listening to Music," "What I Enjoy Reading in American Literature," "A Collection of Anthologies of Art, Music, and Literature," and "Science Fiction."

\section{Results}

This project has been well worth the time and energy exerted by the library staff. The students have demanded that the contest become an annual event. Many desirable book objectives, important to the lives of those who are being served in the college community, are being fulfilled through this program. Books are becoming more pleasurable and profitable, books are becoming a more integral part of the students' life, books are awakening the love of reading. The students have learned to think in terms of collecting a good personal library around a central theme. They have expressed their pleasure in gathering their libraries. They have learned the art of bargain hunting for good inexpensive reprint and secondhand books.

To hear the students avidly discussing their collections, telling about their book trips and their "finds," advising each other on authors and books, over a cup of coffee at the campus tea-house shows that many of the students have been inoculated with the virus of bibliomania. 